Ekonomia - Wroclaw Economic Review 26/3 (2020)

Acta Universitatis Wratislaviensis

No 4008

https://doi.org/10.19195/2658-1310.26.3.1

Urszula Banaszczak-Soroka

ORCID: 0000-0001-6354-0627

Uniwersytet Wrocławski

urszula.banaszczak-soroka@uwr.edu.pl

\title{
Struktura prywatnych wydatków na zdrowie na osobę w krajach UE w latach 2008-2018
}

Artykuł nadesłany: 5.08.2020; artykuł zaakceptowany: 30.09 .2020

Kody klasyfikacji JEL: D010, D100, D140, D190, D310, G100, I11

Keywords: consumption, health expenditure, classification of individual consumption by purpose

Abstract

The structure of private expenditure on health per capita in EU countries 2008-2018

Classification of Individual Consumption by Purpose (COICOP). Make health expenditure accepted in European Union statistics into three main categories: medical and pharmaceutical products, medical devices and equipment; outpatient and alternative medicine services, hospital and sanatorium services. This classification also applies to private households on health as part of consumption. The aim is to investigate the structure of health expenditure per capita in the EU-27 in the years 2008-2018.

\section{Wstęp}

Z punktu widzenia nauk ekonomicznych konsumpcję można zdefiniować jako spożycie dóbr materialnych i usług w procesie bezpośredniego zaspokajania potrzeb ludzkich (Włodarczyk-Śpiewak, 2011, 66-70). Podstawową determinantą konsumpcji jest dochód rozporządzalny gospodarstwa domowego, to jest dochód gospodarstwa domowego ${ }^{1}$ pomniejszony o zaliczki na podatki oraz składki na ubezpieczenie społeczne i zdrowotne (Dąbrowska, 2013, 47-82). Sytuacja gospo-

1 Zestawienie komponentów dochodów gospodarstw domowych zawiera rozporządzenie Parlamentu Europejskiego i Rady (UE) nr 549/2013 z dnia 21 maja 2013 roku w sprawie europejskiego systemu rachunków narodowych i regionalnych w Unii Europejskiej (Dz. Urz. EU L 174 z 26.06.2013) - ESA 2010; Metodologia badania budżetów gospodarstw domowych, 2011.

Ekonomia - Wroclaw Economic Review 26/3, 2020

(C) for this edition by CNS 
darstw domowych, biorąc pod uwagę dochód rozporządzalny, była i jest w krajach UE bardzo zróżnicowana. W 2018 roku pierwsze na liście niemieckie gospodarstwa domowe dysponowały kwotą ponad 2 bln euro, a ostatnie w zestawieniu estońskie - 13 mld euro (Banaszczak-Soroka, 2019, 81-85; Milic-Czerniak, 2016, 108-109). Znaczna część gospodarstw domowych nie wydatkuje na bieżąco całości dochodów, lecz podejmuje decyzje o częściowej rezygnacji z konsumpcji na rzecz oszczędności (Banaszczak-Soroka, 2018, 136-162; Keynes, 2003, 57; Owsiak, 2016, 228-230). Taka postawa implikuje subiektywne i obiektywne decyzje dokonywane przez członków gospodarstwa domowego w obszarze rozdysponowania posiadanych środków zgodnie z przyjętą indywidualną hierarchią potrzeb (Bywalec, 2009, 139; Zalega, 2007, 9).

W ramach ESA 2010 w rozdziale 23 Klasyfikacje, w części Klasyfikacja spożycia indywidualnego według celu (Miczyńska-Kowalska, 2001, 112-113) wymieniono 12 zasadniczych grup: żywność i napoje bezalkoholowe; napoje alkoholowe, wyroby tytoniowe, narkotyki; odzież i obuwie; użytkowanie mieszkania lub domu, zaopatrzenie w wodę, energię elektryczną, gaz i inne paliwa; wyposażenie mieszkania i prowadzenie gospodarstwa domowego; zdrowie; transport; łączność; rekreacja i kultura; edukacja; restauracje i hotele; pozostałe wydatki na towary i usługi. W Klasyfikacji spożycia indywidualnego według celu (ang. COICOP — Classification of Individual Consumption by Purpose, przygotowana i rekomendowana przez ONZ), którą wprowadzono w UE rozporządzeniem Komisji (WE) nr 113/2002 z dnia 23 stycznia 2002 roku$^{2}$, wskazano trzy grupy wydatków na zdrowie w ramach konsumpcji gospodarstw domowych:

a) artykuły medyczno-farmaceutyczne, urządzenia i sprzęt medyczny, na przykład leki, surowice, szczepionki, zioła, zielarskie produkty farmaceutyczne, tran, urządzenia terapeutyczne, okulary, protezy kończyn, protezy zębowe, obuwie ortopedyczne, materiały chirurgiczne i opatrunkowe, aparaty słuchowe, termometry, smoczki i inne;

b) usługi ambulatoryjne i medycyny niekonwencjonalnej, na przykład opłaty za porady lekarskie, za wykonywanie zabiegów chirurgicznych, zdjęcia rentgenowskie, USG, EKG, usługi dentystyczne i protetyczne, robienie zastrzyków, wykonywanie zabiegów pielęgnacyjnych usługi pogotowia ratunkowego, medycyna niekonwencjonalna i inne;

c) usługi szpitalne i sanatoryjne, na przykład opłaty za przebywanie w szpitalu, opłaty administracyjne związane z leczeniem w szpitalu (zakwaterowanie, wyżywienie), wykonywanie zabiegów chirurgicznych, usługi dentystyczne, op-

${ }^{2}$ Od 2016 roku obowiązuje rozporządzenie Komisji Europejskiej (UE) 2015/359 z dnia 4 marca 2015 roku wykonujące rozporządzenie Parlamentu Europejskiego i Rady (WE) nr 1338/2008 w odniesieniu do statystyk dotyczących wydatków i finansowania opieki zdrowotnej (Dz.Urz. UE L 62/6 z 6.03.2015). 
tyczne, kręglarskie, opłaty związane z leczeniem sanatoryjnym i w zakładach rehabilitacyjnych i inne ${ }^{3}$.

Celem niniejszego opracowania jest zbadanie struktury wydatków na zdrowie per capita (w cenach bieżących) w krajach UE w latach 2008-2018, przyjmując za punkt wyjścia podstawową klasyfikację COICOP. Hipoteza — w krajach UE nie występuje jeden wzorzec struktury prywatnych wydatków na zdrowie. Można jednak wskazać charakterystyczne dla grup krajów priorytety w nabywaniu produktów i usług medycznych.

$\mathrm{W}$ artykule wykorzystano następujące metody badawcze: analizę literatury ekonomicznej i aktów prawnych oraz ilościową analizę danych statystycznych pozyskanych z baz Eurostatu. Wynik - na podstawie przeprowadzonych badań należy pozytywnie zweryfikować przyjętą hipotezę badawczą. Oryginalność/wartość - artykuł porusza ważny temat odnoszący się do badania struktury prywatnych wydatków na zdrowie per capita w krajach UE. Podjęcie tego tematu może stanowić przyczynek do dalszych badań, szerszego rozpatrzenia zagadnienia nie tylko w ujęciu ilościowym (jak w artykule), lecz uwzględniającym także wiele aspektów jakościowych, jak: organizacja prawna i funkcjonalna ochrony zdrowia, stan zdrowia mieszkańców i ich potrzeby, ceny usług medycznych i lekarstw, nowe technologie medyczne, choroby i śmiertelność, struktura demograficzna, wykształcenie, miejsce zamieszkania i wiele innych, co zapewne wzmocni walory poznawcze badanej kwestii (Piekut, Gutkowska, 2016, 36-44).

\section{Analiza prywatnych wydatków na zdrowie (na osobę) w krajach UE z dominującym udziałem usług ambulatoryjnych}

W pięciu krajach: Portugalia, Włochy, Cypr, Holandia i Finlandia preferowane były wydatki na usługi ambulatoryjne. Ich udział w wydatkach na zdrowie, średnio w badanym okresie, oscylował w granicach 50\%. Najwięcej pieniędzy na ten cel, per capita, wydatkowali Portugalczycy, średnio w badanym okresie 59\% z puli przeznaczonej na zdrowie. Mieszkaniec Portugalii w 2008 roku wydawał na tę grupę usług 290 euro, a 11 lat później - 442 euro (wzrost o $52 \%$ ). Na drugiej pozycji znalazły się wydatki na produkty medyczno-farmaceutyczne z udziałem w wydatkach ogółem na poziomie $35 \%$. W tej kategorii wydatki wzrosły w latach 2008-2018 tylko o 3\% (z 234 euro w 2008 roku do 242 euro w 2018). Najmniej pieniędzy Portugalczyk przeznaczał na hospitalizację,

${ }^{3}$ W 2018 roku opublikowana została nowa klasyfikacji wydatków na zdrowie w ramach indywidualnego spożycia (konsumpcji) Classification of Individual Consumption According to Purpose (COICOP), United Nations, New York, 2018, Statistical Papers, Seria M, nr 99, s. 36 oraz 103-116; https://unstats.un.org/unsd/classifications/unsdclassifications/COICOP_2018_-_pre-edited_white_cover_version_-_2018-12-26.pdf (dostęp: 5.04.2020).

Ekonomia - Wroclaw Economic Review 26/3, 2020

(C) for this edition by CNS 
około 15\%, zwiększając wydatki na ten cel o $21 \%$ (z 29 euro w 2008 roku do $35 \%$ w 2018).

Cypryjczyk w badanym okresie na usługi ambulatoryjne średnio przeznaczał blisko 50\% środków z puli przeznaczonej na zdrowie. Wydatki w tej kategorii w latach 2008-2018 wzrosły o 16\% (z 391 do 452 euro). Na drugim miejscu preferowane były wydatki na produkty medyczne z blisko $30 \%$ udziałem w strukturze wydatków ogółem. Także w tej kategorii wydatki wzrosły o 18\% (z 224 euro w 2008 roku do 264 w 2018). Największy wzrost dotyczył wydatków na hospitalizację - blisko 60\% (z 126 euro w 2008 roku do 206 w 2018). Po 47\% z prywatnych budżetów przeznaczonych na zdrowie wydatkowali na usługi ambulatoryjne Włosi i Holendrzy. Mieszkaniec Włoch w badanym okresie zwiększył wydatki na ten cel o 24\% (z 245 euro w 2008 roku do 304 w 2018), a mieszkaniec Holandii o 41\% (z 219 euro w 2008 roku do 310 w 2018). Drugie miejsce, podobnie jak $\mathrm{w}$ innych krajach tej grupy, zajmowały wydatki na produkty medyczne. We Włoszech było to $38 \%$, a w Holandii - 30\%. Włoch zwiększył zakupy usług i produktów medyczno-farmaceutycznych o 6\% (z 173 euro w 2008 r do 187 w 2018), a Holender o prawie identyczny wymiar (z 215 euro w 2008 roku do 228 w 2018). Najmniej, średnio w badanym okresie, w obu krajach mieszkańcy przeznaczali na hospitalizację. We Włoszech $15 \%$, a w Holandii $22 \%$. W tej kategorii we Włoszech wydatki wzrosły o 29\% (z 71 euro w 2008 do 92 w 2018), a w Holandii o ponad 40\% (z 104 euro w 2008 roku do 146 w 2018) (zob. rysunek 1).

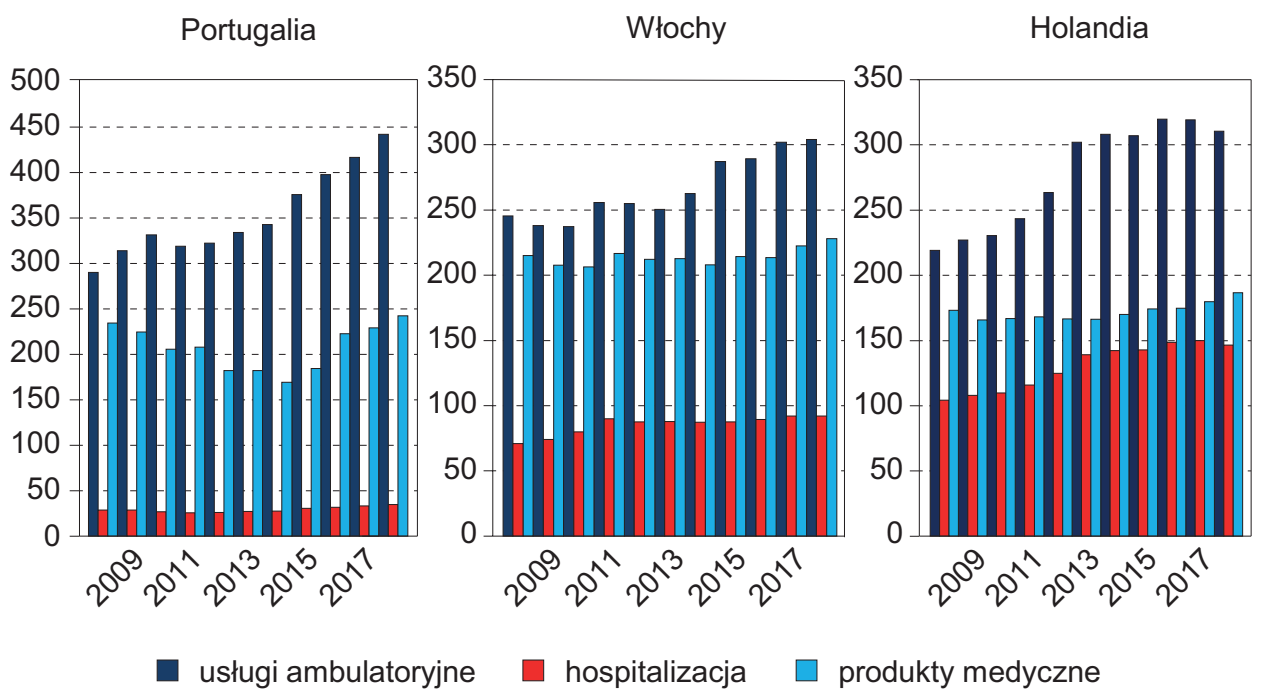

Rysunek 1. Wybrane kraje UE z preferencją prywatnych wydatków (per capita) na usługi ambulatoryjne w latach 2008-2018 (w euro)

Źródło: Obliczenia i opracowanie własne na podstawie danych Eurostatu: Final consumption expenditure of households by consumption purpose (COICOP 3 digit) [nama_10_co3_p3], https://ec.europa.eu/eurostat/web/products-datasets/product?code=nama_10_co3_p3 (dostęp: 22.07.2020); Population on 1 January, https://appsso.eurostat.ec.europa.eu/nui/show.do?dataset=demo_pjan\&lang=en (dostęp: 22.07.2020). 


\section{Analiza prywatnych wydatków na zdrowie (na osobę) w krajach UE z dominującym udziałem finansowania hospitalizacji}

Irlandczycy i Belgowie, jako nieliczni w UE, preferowali wydawanie własnych pieniędzy głównie na hospitalizację. Przeznaczali na ten cel, średnio w badanym okresie, blisko 50\% środków własnych w ramach wydatków na zdrowie ogółem. Irlandczyk w 2008 roku nabywał usługi szpitalne za około 287 euro, a 11 lat później — za 465 euro (wzrost o blisko 62\%). Wydatki na szpitale mieszkańca Irlandii rosły dynamicznie do 2012. W kolejnych latach obserwujemy wyhamowanie, a następnie ustabilizowanie wielkości środków przeznaczonych na ten cel. Co interesujące, w 2018 roku finansowanie hospitalizacji przez Irlandczyka nie osiągnęło poziomu najwyższych wydatków z tej kategorii z roku 2012, to jest 510 euro. Belg w 2008 roku nabywał usługi związane z hospitalizacją za taką kwotę, jaką Irlandczyk przeznaczał na ten cel w 2018 roku, zwiększając ją o $76 \%$ do roku 2018.

Rozkład wydatków na dwie pozostałe kategorie, to jest usługi ambulatoryjne i produkty medyczne, w tych krajach był nieco inny. Mieszkaniec Irlan dii, średnio w badanym okresie, na produkty medyczne i usługi ambulatoryjne przeznaczał odpowiednio 20 i $31 \%$ z kwoty przeznaczonej na zdrowie, a Belg 27 i 25\%. W okresie 11 lat mieszkaniec Irlandii dynamizował wydatki na usługi ambulatoryjne (wzrost o 60\%), a zmniejszał, szczególnie w okresie 2008-2012, wydatki na zakup produktów medycznych (spadek około 10\%). W 2008 roku mieszkaniec Belgii na produkty medyczne wydatkował 275 euro, a w 2018 roku -350 euro (wzrost o 27\%), natomiast na usługi ambulatoryjne adekwatnie 255 i 318 euro (wzrost o 24\%).

Do grupy tej zaliczono także, bardzo specyficzną w rozkładzie wydatków, Grecję. Średnio w badanym okresie Grek wydawał na usługi ambulatoryjne około $48 \%$, na hospitalizację $35 \%$, a na produkty medyczne $20 \%$ środków przeznaczonych na zdrowie. Analizując badany okres, na uwagę zasługuje istotna zmiana preferencji co do kierunków finansowania zdrowia. O ile w 2008 roku na usługi ambulatoryjne mieszkaniec Grecji przeznaczał 454 euro, o tyle w 2018 roku, 156 euro (blisko 300 euro mniej w stosunku do 2008 roku), na hospitalizację zaś adekwatnie 194 euro, a w 2018 roku 235 euro (ponad 40 euro więcej, to jest $21 \%$ ) (zob. rysunek 2). 


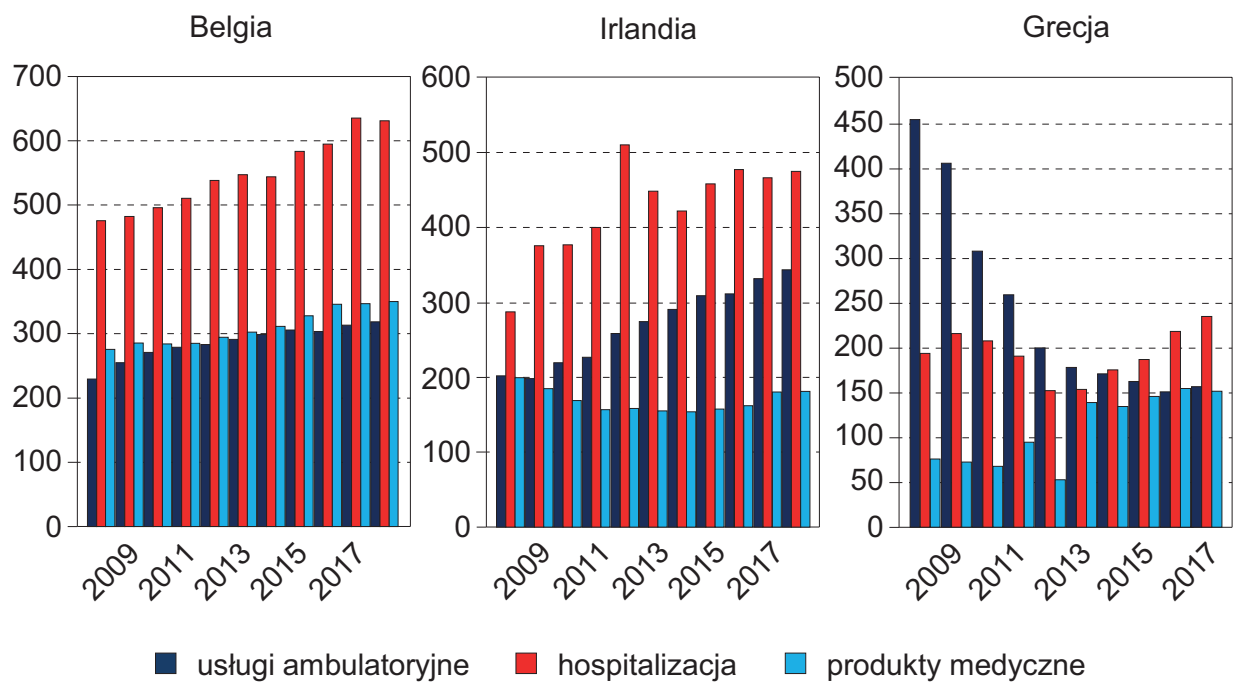

Rysunek 2. Wybrane kraje UE z preferencją prywatnych wydatków (per capita) na hospitalizację w latach 2008-2018 (w euro)

Źródło: obliczenie i opracowanie własne na podstawie danych Eurostatu: Final consumption expenditure of households by consumption purpose oraz Population on 1 January.

\section{Analiza prywatnych wydatków na zdrowie (per capita) w krajach UE z dominującym udziałem produktów medyczno-farmaceutycznych w wydatkach na zdrowie ogółem}

Najliczniejsza grupa krajów w UE charakteryzuje się przewagą wydatków prywatnych na produkty z kategorii medyczno-farmaceutycznych. Mieszkańcy pięciu krajów UE ponosili nakłady na tę kategorię usług i produktów, średnio w badanym okresie, przekraczające $60 \%$ udziału w wydatkach na zdrowie ogółem, a byli to: Litwini (71\%), Słowacy (68\%), Rumuni i Bułgarzy (67\%) oraz Polacy (65\%). Najbardziej dynamicznie, nie tylko w tej grupie, ale w całej UE, rosło prywatne finansowanie produktów medyczno-farmaceutycznych w Bułgarii, przekładając się na wzrosty wydatków o $300 \%$ (z 58 euro w 2008 roku do 228 w 2028), w Rumunii - wzrost o 268\% (z 76 euro w 2008 roku do 280 w 2028), dalej nieco wolniej w Polsce - wzrost o 108\% (z 142 euro w 2008 roku do 296 w 2018) i Słowacji wzrost o $78 \%$ (z 75 euro w 2008 roku do 134 w 2018), a najwolniej na Litwie - wzrost o 37\% (adekwatnie z 214 euro do 293 euro). W tej grupie w trzech krajach: w Polsce, na Litwie i w Rumunii obserwujemy, średnio w badanym okresie, zaledwie kilkuprocentowy udział wydatków na hospitalizację w wydatkach ogółem. Odpowiednio: w Rumunii 2,4\%, w Polsce 2,6\% oraz na Litwie 4,4\%. W Polsce i na Litwie odnotowano przyrosty wydatków na hospi- 
talizację o $87 \%$ (z 6,5 euro w 2008 roku do 12,2 euro w 2018), a na Litwie 70\% (adekwatnie z 11,1 euro do 18,8 euro). Natomiast w Rumunii wystąpiła tendencja zmniejszania wydatków na ten cel przez mieszkańca tego kraju (spadek czterokrotny z 20,2 euro w 2008 roku do 4,8 euro w 2018 roku). W odniesieniu do usług ambulatoryjnych, w relacji do wydatków prywatnych ogółem na osobę, Litwini przeznaczali $24 \%$ środków na zdrowie ogółem, Rumuni $31 \%$, a Polacy $32 \%$. We wszystkich krajach obserwujemy dodatnie przyrosty finansowania tej kategorii usług i produktów: na Litwie o $89 \%$, w Rumunii o $64 \%$, w Polsce zaś o $56 \%$. W dwóch krajach, w Bułgarii i na Słowacji, wydatki na hospitalizację ponoszone ze środków własnych mieszkańca, średnio w badanym okresie, oscylowały w granicach $17 \%$ — przy ich wzroście na Słowacji o 93\% (z 16 euro w 2008 roku do 29,4 w 2018 roku), a w Bułgarii o 34\% (z 38 euro w 2008 roku do 51 w 2018 roku). Na usługi ambulatoryjne mieszkaniec Bułgarii wydawał w 2008 roku 43 euro, a w 2018 - 39 (zmniejszenie wydatków o 10\%), mieszkaniec Słowacji zaś adekwatnie 30 euro i 39 euro (wzrost o 30\%).

W czterech krajach UE mieszkańcy, z własnych środków, wydatkowali średnio w badanym okresie na produkty medyczno-farmaceutyczne w granicach $50-60 \%$ środków finansowych przeznaczonych na zdrowie ogółem. Zaliczono do tej grupy takie kraje, jak: Estonia i Czechy (wydatki na poziomie 57\%) oraz Węgry (wydatki na poziomie 51\%) Najbardziej dynamicznie, na tę kategorię medyczną, w ciągu 11 lat zwiększyli pulę środków pieniężnych Estończycy — wzrost o 64\% (z 106 euro w 2008 roku do 174 w 2018 roku), znacznie mniej Czesi - wzrost o 27\% (adekwatnie 106 i 135 euro), a najmniej Węgrzy, wzrost o 11\% (adekwatnie 121 euro i 135 euro). Jako drugą grupę wydatków wybierał Estończyk, Węgier i Czech usługi ambulatoryjne, które stanowiły w wydatkach ogółem średnio odpowiednio 27\%, 40\% i 35\%. W tych trzech krajach na hospitalizację Estończyk przeznaczał, średnio badanym okresie, około 16\%, a Węgier i Czech około 8\%. W 2008 roku mieszkaniec Estonii wydał na hospitalizację 26 euro, a w 2018 roku 46 euro (wzrost o 77\%), mieszkaniec Czech adekwatnie 18,5 i 19,5 euro (wzrost o 5\%), a mieszkaniec Węgier 20 i 23 euro (wzrost o 15\%) (zob. rysunek 3).

$\mathrm{W}$ trzech krajach wydatki na produkty medyczne były bliskie połowie wydatków na zdrowie ogółem. To mieszkańcy Słowenii (wydatki w wysokości 49,2\%), Luks emburga (48\%) oraz Niemiec (46\%). Słoweniec zwiększył swoje wydatki, w badanym okresie, o 74\% (z 160 euro w 2008 roku do 227 w 2018), Luksemburczyk o 4,5\% (adekwatnie 350 i 366 euro), a Niemiec o 42\% (adekwatnie 344 i 488 euro). Kolejny kierunek wydatkowania prywatnych środków finansowych w tych trzech krajach to usługi ambulatoryjne. Słoweniec i Luksemburczyk na ten cel kierowali 38\% środków finansowych przeznaczonych na zdrowie, a Niemiec 33\%. W grupie usług ambulatoryjnych największy przyrost w ciągu 11 lat wystąpił u mieszkańców Luksemburga — ponad 200\%, u mieszkańców Niemiec $-28 \%$ oraz o $23 \%$ u mieszkańca Słowenii. Dopiero na trzecim miejscu znalazło się finansowanie ze środków własnych usług szpitalnych. W Luksemburgu i Sło- 


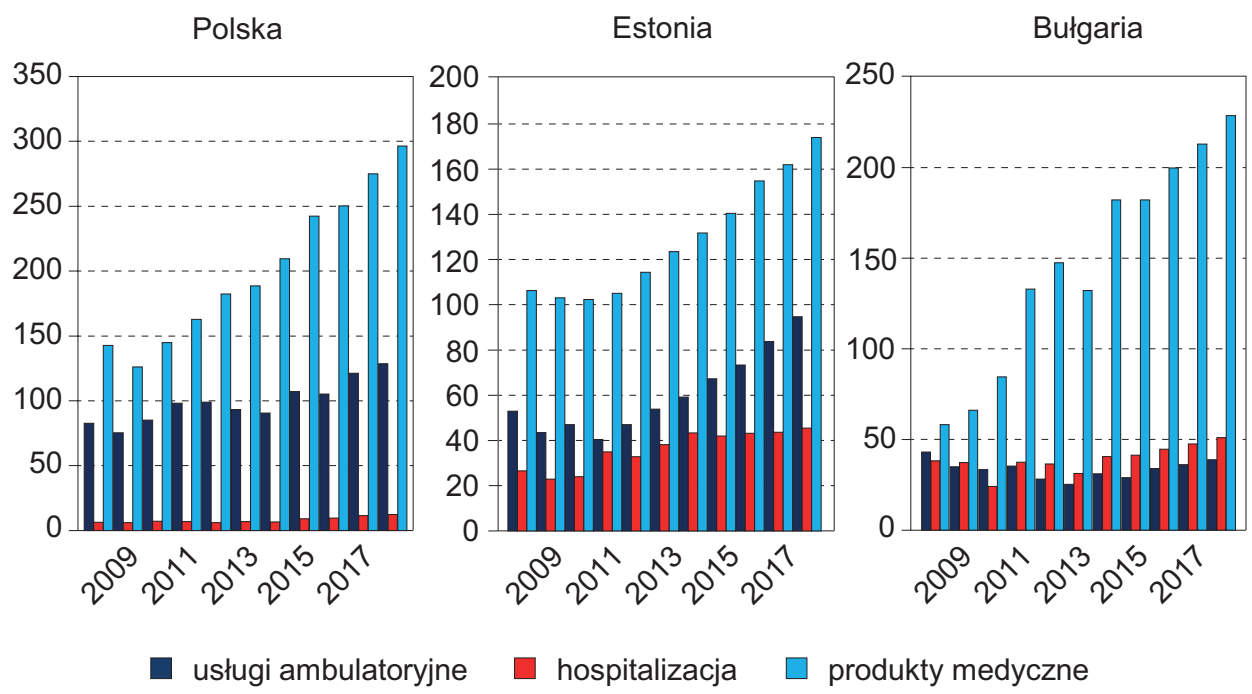

Rysunek 3. Wybrane kraje UE z preferencją prywatnych wydatków (per capita) na produkty medyczne w latach 2008-2018 (w euro)

Źródło: obliczenie i opracowanie własne na podstawie danych Eurostatu: Final consumption expenditure of households by consumption purpose oraz Population on 1 January.

wenii wydatkowano około $13 \%$ z puli wydatków na zdrowie, a w Niemczech $21 \%$. Także tu obserwujemy zwiększanie nakładów na usługi szpitalne: w Luksemburgu o 169\% (z 59 euro w 2008 roku do 159 w 2018), na Słowenii o 37\% (adekwatnie 49 i 67 euro) oraz o tę samą wielkość w Niemczech (adekwatnie 163 i 221 euro) (zob. rysunek 4).

To grupy tej została zaliczona też Malta. Średnio w badanym okresie połowa środków finansowych mieszkańca przeznaczonych na zdrowie kierowana była na produkty medyczne. Obserwujemy jednak w tym kraju przesunięcie środków finansowych z produktów medycznych ku usługom ambulatoryjnym, co w ostatnich latach doprowadziło do zrównania tych wartości. Podobnie dzieje się w Luksemburgu. Nakłady na produkty medyczne ponoszone przez mieszkańca Malty w badanym okresie lekko wzrosły — z 230 euro w 2008 roku do 242 w 2018 roku, to jest wzrost o 5\%, a na usługi ambulatoryjne, które zajmują drugie miejsce w strukturze wydatków, odnotowano wzrost o 73\% (z 138 euro w 2008 roku do 239 w 2018). Mieszkaniec Malty na hospitalizację przeznaczał około 10\% budżetu dotyczącego zdrowia. Także w tej grupie wydatków odnotowano wzrost nakładów — około 11\% (z 43 euro w 2008 roku do 48 w 2018) (zob. rysunek 4). 


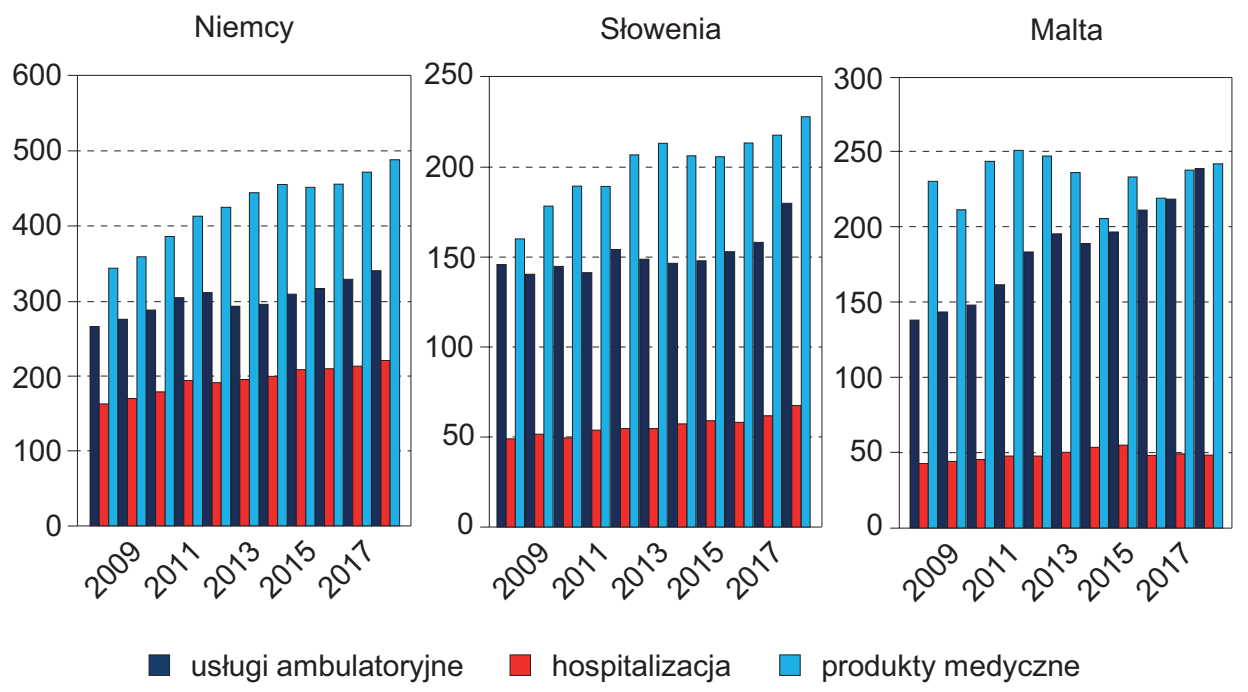

Rysunek 4. Wybrane kraje UE z preferencją prywatnych wydatków (per capita) na produkty medyczne w latach 2008-2018 (w euro)

Źródło: obliczenie i opracowanie własne na podstawie danych Eurostatu: Final consumption expenditure of households by consumption purpose oraz Population on 1 January.

\section{Analiza prywatnych wydatków na zdrowie (na osobę) w krajach UE z proporcjonalnym rozkładem finansowania usług ambulatoryjnych oraz produktów medycznych}

Mieszkańcy siedmiu krajów UE: Francji, Chorwacji, Danii, Austrii, Szwecji, Hiszpanii i Łotwy, średnio w badanym okresie, finansowali proporcjonalnie usługi ambulatoryjne oraz produkty medyczne. Proporcje co do podziału wydatków w tych kategoriach usług w wymienionych krajach były heterogeniczne. W Szwecji i Chorwacji podział ten był bliski proporcji 50\% na $50 \%$. Na hospitalizację mieszkaniec Szwecji przeznaczał zaledwie 3\% wydatków, a Chorwacji około 6\%. W 2008 roku mieszkaniec Szwecji zapłacił za usługi ambulatoryjne 254 euro, a w 2018 roku - 307 (to jest wzrost o 21\%), natomiast za produkty medyczne zapłacił adekwatnie 246 euro oraz 306 euro (to jest wzrost o 24\%). Mieszkaniec Chorwacji w 2008 roku wydatkował na usługi ambulatoryjne 166 euro, a w 2018 roku 175 (wzrost o 5\%). Wydatki na produkty medyczne, biorąc pod uwagę rok 2008 i 2018, nie uległy zmianie i utrzymały się na poziomie 168 euro.

We Francji, Danii i na Łotwie mieszkaniec tych krajów, średnio w badanym okresie, przeznaczał na hospitalizację około $15 \%$ z puli środków przeznaczonych na zdrowie, a pozostałe dzielił prawie proporcjonalnie na usługi ambula- 
toryjne i medyczno-farmaceutyczne. Francuz w 2008 roku na te pierwsze usługi przeznaczył w 2008 roku 294, a 11 lat później - 349 euro (to jest wzrost o 19\%), na te drugie odpowiednio 276 i 289 euro (to jest wzrost 5\%). W trzeciej kategorii — hospitalizacja, wydatki wzrosły o 18\% w badanym okresie. Duńczyk w 2008 roku na usługi ambulatoryjne wydał ze środków własnych 214 euro, a 2018 roku 284 euro (odnotowano wzrost o 34\%), na artykuły medyczno-farmaceutyczne odpowiednio zaś 244 i 298 euro (to jest wzrost o $22 \%$ ). W przypadku wydatków na hospitalizację zanotowano wzrost finansowania o $12 \%$. Mieszkaniec Łotwy w 2008 roku na usługi ambulatoryjne wydał 114, a 11 lat później — 169 euro (przyrost o 48\%), natomiast na produkty i usługi medyczno-farmaceutyczne odpowiednio 98 i 158 euro (co oznacza wzrost wydatków 61\%). Wydatki na hospitalizację na Łotwie wzrosły w badanym okresie o $381 \%$ z poziomu 16 euro w 2008 roku do $77 \mathrm{w} 2018$.
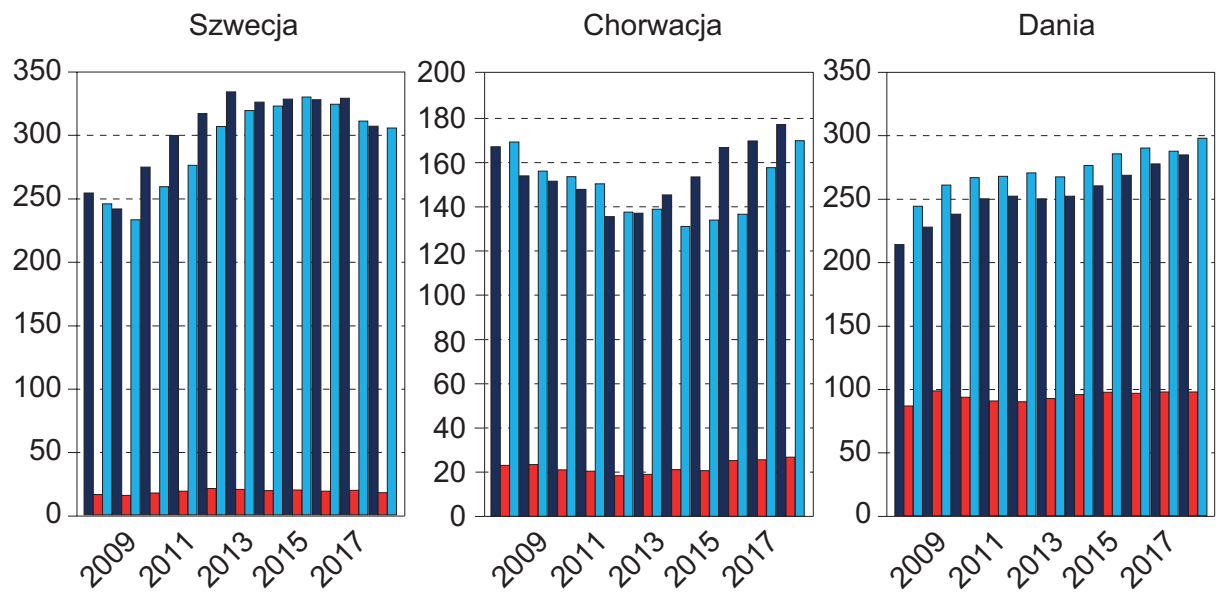

Rysunek 5. Wybrane kraje UE o proporcjonalnym rozłożeniu prywatnych wydatków na zdrowie (na osobę) w kierunku usług ambulatoryjnych oraz produktów medycznych w latach 2008-2018 (w euro)

Źródło: obliczenia i opracowanie własne na podstawie danych Eurostatu: Final consumption expenditure of households by consumption purpose oraz Population on 1 January.

Mieszkaniec Hiszpanii na hospitalizację przeznaczał, średnio w badanym okresie, $11 \%$ z puli budżetu przeznaczonego na zdrowie, a pozostałe środki dzielił proporcjonalnie na usługi ambulatoryjne oraz produkty medyczno-farmaceutyczne. Finansowanie hospitalizacji wzrosło w Hiszpanii w ciągu 11 lat o 45\% (z 53 euro w 2008 roku do 77 w 2018). Prywatne wydatki na usługi ambulatoryjne wzrosły w tym czasie o $10 \%$ (z 255 euro w 2008 roku do 281 w 2018), a na produkty medyczne o 46\% (adekwatnie z 188 do 276 euro). Najwięcej na hospitalizację, średnio w badanym czasie, wydatkowali mieszkańcy Austrii - około $20 \%$, a pozostałe wydatki rozkładali równomiernie po $40 \%$ na dwie pozostałe 
kategorie. W badanym okresie wydatki na hospitalizację wzrosły o 16\% (z 155 euro w 2008 roku do 181 w 2018), na usługi ambulatoryjne i produkty medyczno-farmaceutyczne o tę samą wartość w ujęciu zarówno procentowym, jak i wartościowym, to jest o $31 \%$ (adekwatnie z 256 do 337 euro).

\section{Wnioski}

Bezpieczeństwo zdrowotne jest jedną z kluczowych sfer życia człowieka. Naturalną, wręcz oczywistą kwestią jest, że ludzie chcą być zdrowi. Jednym ze źródeł finansowania produktów i usług związanych ze zdrowiem (oprócz środków publicznych, które powinny przeważać w strukturze wydatków na ten cel oraz środków zagranicznych) są środki własne gospodarstw domowych wydzielone w strukturze konsumpcji. Badając strukturę prywatnych wydatków na zdrowie na osobę, w 27 krajach UE zauważalne są pewne tendencje co do zasadniczych kierunków ich wydatkowania. Opierając się na klasyfikacji COICOP, możemy wskazać kraje z dominującym udziałem (ponad 50\%) w strukturze wydatków ogółem na zdrowie:

1. usług ambulatoryjnych (Portugalia, Włochy, Cypr, Holandia, Finlandia),

2. wydatków na usługi szpitalne (Irlandia, Belgia i Grecja),

3. produktów medyczno-farmaceutycznych (Litwa, Bułgaria, Rumunia, Słowacja, Estonia, Polska, Czechy, Węgry, Malta, Luksemburg, Niemcy i Słowenia) oraz

4. proporcjonalnym podziałem środków na usługi ambulatoryjne i medyczno-farmaceutyczne (Szwecja, Chorwacja, Francja, Dania, Łotwa, Hiszpania, Austria).

Uwzględniając wielkość prywatnych wydatków na zdrowie, najwięcej na usługi ambulatoryjne w 2008 roku przeznaczał mieszkaniec Grecji (454 euro), a najmniej Słowak (30 euro). Mieszkaniec Grecji wydał na usługi ambulatoryjne, z prywatnych środków, 15 razy więcej niż Słowak. W 2018 roku na pierwszym miejscu uplasowali się Finowie (500 euro), na ostatnim zaś Bułgarzy (39 euro). Dysproporcja między Francuzami a Bułgarami w nabywaniu usług ambulatoryjnych w 2018 roku zmniejszyła się w stosunku tych samych wielkości w 2008 roku sześciokrotnie. W strukturze wydatków na tę kategorię usług medycznych, średnio w badanym okresie, najwięcej środków przeznaczał z całości budżetu na zdrowie Portugalczyk (59\%), a najmniej Bułgar (15\%). W ciągu 11 lat najszybciej na ten cel wydatki wzrosły w Luksemburgu - o 212\%. Zmniejszenie w badanym okresie środków przeznaczonych na usługi ambulatoryjne odnotowano w kilku krajach, na przykład w Bułgarii czy na Litwie — około 10\%. Na usługi szpitalne najwyższą kwotę w krajach UE w 2008 roku przeznaczał Belg (475 euro), a najmniejszą Polak — blisko 50 razy mniej. W 2018 roku podobnie jak w 2008 roku mieszkaniec Belgii dominował pod względem wydatków na hospitalizację 
w krajach UE, przeznaczając na ten cel 630 euro. Aż o 130 razy mniej od Belga przeznaczał na hospitalizację Rumun. Usługi medyczne przeważały w wydatkach u mieszkańca Belgii, stanowiły blisko $50 \%$ budżetu ogółem przeznaczonego na zdrowie; u mieszkańca zaś Polski jedynie 2,6\%. Największy przyrost środków finansowych przeznaczonych na ten cel, w badanym okresie, wystąpił na Łotwie. Mieszkaniec tego kraju zwiększył nakłady aż o 360\%, a mieszkaniec Czech tylko o 5\%. Najwięcej krajów UE charakteryzuje się bardzo wysokim udziałem, średnio w badanym okresie, wydatków na produkty medyczno-farmaceutyczne w strukturze wydatków ogółem. Na tę kategorię zdrowia, w strukturze wydatków, najwięcej przeznaczali Litwini (71\%), najmniej Bułgarzy (15\%). Należy podkreślić, że taki priorytet $\mathrm{w}$ wydatkach (nabywanie produktów medyczno-farmaceutycznych) charakterystyczny jest przede wszystkim dla krajów Europy Środkowo-Wschodniej. Wydaje się, że tak wysoki udział tej kategorii w wydatkach ogółem związany jest z tym, że są to dobra prymarne. Lekarstwa, okulary, termometry, smoczki, materiały opatrunkowe, zioła i inne tworzą podstawę bieżącego dbania o zdrowie. Natomiast usługi ambulatoryjne oraz usługi szpitalne jako dobra wyższego rzędu są wybierane powszechniej w krajach o wyższym dochodzie rozporządzalnym gospodarstwa domowego. Kwotowo na produkty z tej grupy najwięcej w 2008 roku wydatkował mieszkaniec Niemiec (344 euro), a najmniej mieszkaniec Grecji (76 euro), na koniec badanego okresu odpowiednio mieszkaniec Luksemburga (366 euro), a najmniej mieszkańcy Czech, Słowacji i Węgier — po 135 euro.

Analiza dynamiki zmian, w całym badanym okresie, wskazuje kilka trendów zachowań konsumenckich w zakresie prywatnego finansowania wydatków na zdrowie. Trend pierwszy to systematyczny wzrost wydatków rok do roku na wszystkie trzy kategorie usług i produktów medycznych. Takich krajów było dziewięć. Między innymi charakterystyczne było to u mieszkańców Belgii, Włoch, Holandii czy Austrii. Drugi trend to bardzo dynamiczny wzrost wydatków na jedną grupę produktów i usług medycznych, przede wszystkim wydatków na produkty medyczne. Taką tendencję można zauważyć w sześciu krajach, które wstąpiły do UE w lub po 2004 roku. W tej grupie znajdują się Polska, Rumunia, Estonia czy Bułgaria. Trzeci trend można zaobserwować w Luksemburgu, na Malcie, w Grecji czy Hiszpanii, w których nastąpiła zmiana preferencji co do kierunków wydatkowania prywatnych środków na zdrowie w dwóch kategoriach: usługi ambulatoryjne na produkty medyczne lub przeciwnie. Należy także podkreślić, że w wielu krajach wystąpiło roczne lub kilkuletnie zmniejszenie prywatnych wydatków na zdrowie. Zjawisko takie to także konsekwencja kryzysu z 2007 roku, który dotknął gospodarki wielu krajów świata pogłębione kryzysami lokalnymi. Tak było między innymi w Grecji, Hiszpanii, Portugali, w Szwecji czy Chorwacji ${ }^{4}$.

${ }^{4}$ O przyczynach i konsekwencjach kryzysów lokalnych gospodarek zob. Leśniewski, 2015, 29-39; Kubin, 2018, 90-107; Sporek, 2013, 57-86. 


\section{Bibliografia}

Banaszczak-Soroka, U. (2019). Dochody własne a prywatne wydatki na zdrowie gospodarstw domowych w Krajach UE. W W. Nowak, K. Szalonka (red.), Zdrowie i style życia. Wyzwania ekonomiczne i społeczne. Wrocław: Uniwersytet Wrocławski, WPAiE, e-Monografie nr 153.

Banaszczak-Soroka, U. (2018). Wielkość i struktura oszczędności gospodarstw domowych krajów UE w kontekście planu inwestycyjnego dla Europy. W E. Pancer-Cybulska, K. Biegun (red.), Wybrane aspekty w Czym żyje Unia Europejska. Wybór zagadnień. Wrocław: Uniwersytet Ekonomiczny we Wrocławiu.

Bywalec, C. (2009). Ekonomika i finanse gospodarstw domowych. Warszawa: Wydawnictwo Naukowe PWN.

Classification of Individual Consumption According to Purpose (COICOP) 2018. United Nations New York (2018), „Statistical Papers”, Seria M, nr 99. Data dostępu: 5.04.2020, https://unstats.un.org/unsd/classifications/unsdclassifications/COICOP_2018_-_pre-edited_white_cover_version_-_2018-12-26.pdf.

Dąbrowska, A. (2013). Sytuacja finansowa polskich gospodarstw domowych. W A. Dąbrowska, M. Janoś-Kresło, T. Słaby, J. Witek, Niedobory konsumpcji w polskich gospodarstwach domowych. Warszawa: SGH.

Eurostat. Final consumption expenditure of households by consumption purpose (COICOP 3 digit) [nama_10_co3_p3]. Data dostępu: 22.07.2020, https://ec.europa.eu/eurostat/web/products-datasets/product? code=nama_10_co3 p3.

Eurostat. Population on 1 January. Data dostępu: 22.07.2020, https://appsso.eurostat.ec.europa.eu/ nui/show.do?dataset=demo pjan\&lang=en.

Keynes, J.M. (2003). Ogólna teoria zatrudnienia procentu i pieniądza. Warszawa: PWN.

Kubin, T. (2018). Kryzys gospodarczy w Hiszpanii. Przyczyny, przejawy, następstwa. Studia Ekonomiczne. Zeszyty Naukowe Uniwersytetu Ekonomicznego w Katowicach, 287.

Leśniewski, L. (2015). Skutki globalnego kryzysu finansowego dla rozwoju gospodarczego Danii, Finlandii i Szwecji. Współczesne Problemy Ekonomiczne, 11. Zeszyty Naukowe, 858.

Metodologia badania budżetów gospodarstw domowych. (2011). Warszawa: GUS.

Miczyńska-Kowalska, M. (2001). Istota konsumpcji i zachowań konsumenckich — zarys problematyki. Annales Universitatis Mariae Curie-Skłodowska, Lublin - Polonia, 26, 9.

Milic-Czerniak, R. (2016). Finanse osobiste. Kompetencje - Narzędzia - Instytucje — Produkty Decyzje. Warszawa: Difin.

Owsiak, S. (2016). Finanse. Warszawa: PWE.

Piekut, M., Gutkowska, K. (2016). Wydatki na ochronę zdrowia w gospodarstwach domowych. Polski Przeglad Nauki o Zdrowiu, 1 (46).

Rozporządzenie Komisji Europejskiej (UE) 2015/359 z dnia 4 marca 2015 r. wykonujące rozporządzenie Parlamentu Europejskiego i Rady (WE) nr 1338/2008 w odniesieniu do statystyk dotyczących wydatków i finansowania opieki zdrowotnej (Dz. Urz. UE L 62/6 z 6.03.2015).

Rozporządzenie Parlamentu Europejskiego i Rady (UE) nr 549/2013 z dnia 21 maja 2013 r. w sprawie europejskiego systemu rachunków narodowych i regionalnych w Unii Europejskiej (Dz. Urz. EU L 174 z 26.06.2013) — ESA 2010.

Sporek, T. (2013). Globalne konsekwencje kryzysu finansowego w Grecji. Studia Europejskie, 3.

Włodarczyk-Śpiewak, K. (2011). Konsumpcja jako przedmiot badań ekonomicznych. Ruch Prawniczy, Ekonomiczny i Socjologiczny, 3.

Zalega, T. (2007). Gospodarstwo domowe jako podmiot konsumpcji. Studia i Materiały WZ UW, 1.

Ekonomia - Wroclaw Economic Review 26/3, 2020

(C) for this edition by CNS 